\title{
Understanding the Obama Administration's Syria Policy
}

\author{
Ahmet ATES ${ }^{1}$
}

\begin{abstract}
President Obama's Syria policy and his decision not to intervene in Syria had long been criticized by the US political elites, scholars, and pundits. Most of the explanations of the US policy towards the Syrian civil war are based on realpolitik arguments. Realpolitik explanations of foreign policy analysis tend to overlook other key factors that play a vital role in foreign policy decision making processes. Therefore, these studies fail to explain Obama's Syria policy adequately. This article aims to provide a more comprehensive explanation of Obama's Syria policy. I argue that Obama's Syria policy can be better explained by two other approaches: mass politics and psychological and cognitive approaches. After a thorough examination of relevant literature and President Obama's interviews and speeches, I argue that President Obama chose not to intervene in Syria because US public opinion was extremely reluctant to send US troops to Syria, and there was not an effective interest group that could impact the public opinion and the administration's policies. Further, President Obama's beliefs and attitudes also played a vital role in determining his Syria policy. First, Obama's fundamental beliefs shaped how he approached the Syrian crisis. Then, his interaction with several actors and crises affected his attitude towards Syria and how the situation should be handled. His speeches and interviews show that Libyan intervention affected his perceptions. Therefore, he did not implement the same option in the Syrian case. Likewise, Obama's categorization of the Middle East leaders and threats affected his Syria policy. Last but not least, diplomatic encounters and his personal experience also played a role in determining his Syria policy.
\end{abstract}

Key Words: Syria, Obama, Foreign Policy, Psychological explanations

\section{Obama Yönetimi’nin Suriye Politikasını Anlamak}

\section{$\ddot{\mathrm{Oz}}$}

Başkan Obama'nın Suriye politikası ve Suriye'ye müdahale etmeme kararı ABD'nin siyasi seçkinleri, akademisyenleri ve uzmanları tarafından uzun süredir eleştirilmektedir. Suriye iç savaşına yönelik Amerikan politikasına ilişkin açıklamaların çoğu reel politik argümanlara dayanmaktadır. Reel politik unsurların temel olarak alındığı dış politika analizlerinde karar alma sürecini etkileyen diğer unsurlar göz ardı edilmektedir. Bu sebeple, bu tarz çalışmalar Obama'nın Suriye politikasını yeterli olarak açıklayamamaktadır. Bu makale, Obama'nın Suriye politikasının daha kapsamlı bir açıklamasını sağlamayı amaçlamaktadır. Bu makalede, Obama’nın Suriye politikasının iki yaklaşımla daha iyi açıklanabileceğini savunulmaktadır: kitle politikası ve psikolojik ve bilişsel yaklaşımlar. İlgili literatürün ve Başkan Obama'nın röportajlarının ve konuşmalarının kapsamlı bir şekilde incelenmesi sonucu, ABD kamuoyunun Suriye'ye asker göndermeye son derece isteksiz olmasının ve bu konuda etkili bir çıkar grubunun olmamasının, Başkan Obama'nın Suriye'ye müdahale etmemeyi seçmesine yol açtığı görülmüştür. Dahası, Başkan Obama'nın inanç ve tutumlarının da Suriye politikasını belirlemede hayati bir rol oynadığı savunulmaktadır. Yapılan araştırma sonucunda, Obama'nın temel inançlarının ve Libya müdahalesine yönelik algısının Suriye iç savaşına dair olan tutumunu etkilediği görülmüştür. Aynı şekilde Obama'nın Ortadoğu liderlerini, Ortadoğu'dan gelen tehditleri ve Suriye muhalefetini sınıflandırmasını da karar alma sürecini etkilediği görülmüştür. Son olarak, kişisel diplomatik deneyiminin de Suriye politikasının belirlenmesinde rol oynadığı görülmüştür.

Anabtar Kelimeler: Suriye, Obama, Dış Politika, Psikolojik açılklamalar

\section{Atıf İçin / Please Cite As:}

Ateş, A. (2021). Understanding the Obama administration’s Syria policy. Manas Sosyal Araştırmalar Dergisi, 10(2), 1436-1448.

Geliş Tarihi / Received Date: 06.01.2021

Kabul Tarihi / Accepted Date: 14.01.2021

\footnotetext{
1 Öğretim Görevlisi Dr. - Iğdır Üniversitesi İktisadi ve İdari Bilimler Fakültesi, ahmet.ates@igdir.edu.tr

iD ORCID: 0000-0001-5184-7701
} 


\section{Introduction}

Even though foreign policy has been a vital element of statecraft and international relations, at least in the last century, it has not been studied until the end of the 1950s. Initial studies in the 1950s sought to understand foreign policy decisions in a state-level analysis. Later studies between the 1960s and 1980s, on the other hand, sought to produce generalizable explanations on foreign policy with a systemic level analysis. Cultivation of the field in the following decades resulted in two outcomes: focusing on decisionmaking processes and building decision making models. While some scholars produce models such as the rational actor model and organizational process model, other researchers focused more on features of decision-making processes such as problem definition and interpretation of information. Even though particularities of the literature diverge, most of the studies have one thing in common: the importance of realpolitik in explaining foreign policy decisions.

As in the literature, current analyses on foreign policy decisions also heavily depend on realpolitik assumptions. For instance, President Obama's foreign policy, precisely his Syria policy, has long been questioned and criticized by scholars and policy analysts. Bajevich (2016) accuses President Obama of worsening the Syrian Civil War because of his lack of enthusiasm. Zisser (2013) argues that Obama's Syria policy hurt the US' credibility. Likewise, Weiss (2014) asserts that Obama's indecision played a major role in collapsing local forces such as the Free Syrian Army that fought against Syrian President Bashir Assad. Guiora (2011, p. 270) also stresses the credibility and defines Obama's Syria Policy as "nothing but mere words." Furthermore, Titus (2018) argues that the Syrian Civil War and its complications are a result of Obama's inefficiency in global leadership. Finally, Greenberg (2016) points out that Syria will stain Obama's legacy forever.

As I show a small portion above, critiques of Obama's Syria policy have two things in common: stressing multiple actors in the Syrian conflict and explaining the conflict through realpolitik. For most articles and analyses, Obama's Syrian policy can be best explained by external actors or regional and international politics. From a realpolitik standpoint, President Obama should have built his Syria policy based on realpolitik priorities such as curbing Russian and Iranian influence in Syria and restrain the destabilization of the region. In order to fulfill these priorities, he should have given the green light to military intervention in Syria from the beginning of the conflict. However, contrary to realpolitik priorities, he decided not to intervene in Syria in military terms.

Obama's Syria policy points to a problem both in the literature and current policy analyses: an overdependence on realpolitik arguments in explaining foreign policy decision making. Realpolitik explanations of foreign policy analysis tend to overlook other key factors that play a vital role in foreign policy decision making processes. Therefore, as in Obama's Syria policy, these explanations fail to explain foreign policy decisions adequately. This article contributes to the literature by providing alternative methods/approaches to analyze foreign policy decisions. I argue that Obama's Syrian policy, the decision not to intervene in Syria specifically, can be better explained by two other approaches. The first approach is mass politics explanations. The second approach, on the other hand, is psychological and cognitive explanations.

This article proceeds as follows. First, I provide a brief survey of Obama's foreign policy and Syrian policy. Second, I provide a brief literature review of mass politics, public opinion and interest groups, to understand its role in Obama's Syria policy. Then, I turn my attention to psychological and cognitive explanations. In this section of the article, I provide four psychological theories, namely, self-perception theory, schema theory, cognitive dissonance theory, and attribution theory. In order to explain Obama's Syria policy with psychological and cognitive explanations, I thoroughly review President Obama's interviews published by the Atlantic in 2016. The research conducted shows that mass politics and psychological and cognitive explanations are better approaches to explain Obama's Syria policy than realpolitik explanations.

\section{A Brief Survey of Obama's Foreign Policy and Syria Policy}

\section{Foreign Policy}

Barack Obama had been challenged by several foreign policy issues while he was serving as a president for eight years. However, given the limited time and space, I focus on the major foundations of Obama's foreign policy instead of focusing on and explaining several different foreign policy issues in this section. The foundations of President Obama's foreign policy, specifically Middle East policy, can be 
explained under three categories. The first is his definitions and interpretations of national security. It is specifically important considering the previous President Bush's interpretations of national security. In his Nobel Peace Prize speech on $10^{\text {th }}$ December 2009, Obama cited three conditions as necessary for waging just war: self-defense, proportionality, and the prevention of the direct targeting of civilians (Holland, 2001, p. 59). It is important to note that Obama's approach is "a departure from the affective appeals of the Bush Administration that were predicated on emotive constructs of patriotism and homeland, underlain by a strong belief in American exceptionalism" (Ó Tuathail, 2003 Cited in: Holland, 2011, p. 59). In other words, instead of promoting emotional politics to engage war, President Obama had a different and considerably more just interpretation of waging war. Also, Obama's attitude to how to conduct war differs from the Bush era. Unlike his predecessor, Obama appears to prefer waging war "in the shadows with a light footprint and, if possible limited public scrutiny" (Krieg, 2016, p. 97), which some later labeled as the Obama Doctrine. In other words, as Krieg (2016, p. 104-105) puts it, the Obama Doctrine "emphasizes the need for collective action through coalition warfare and the capacity-building of local partners and allies on the strategic level while it prioritizes covert warfare, relying increasingly on technological platforms, special forces operations, and CIA operatives to achieve strategic and operational objectives out of the public eye on the operational level."

The second foundation of Obama's foreign policy is enhancing the civilian agencies/instruments of US foreign policy and national security. Rejecting the false choice between liberty and security, between safety and ideals, Obama argues that most of the foreign issues are more complex and needed more than a military response; therefore, there should be more diplomatic efforts (Aaronson, 2013, pp.138-139). Acknowledging the need to develop a civilian capacity to wins hearts and minds, Obama committed himself to a greater emphasis on diplomacy that runs by diplomats rather than generals (Aaronson, 2013, p. 145). In that manner, the budget of civilian US agencies such as the State Department dramatically increased comparing the Bush era. For instance, Obama announced a $\$ 400$ billion cut in defense spending (Pavgi, 2011). In other words, as Aaronson (2013, p. 140) puts it, Obama was enthusiastic about upgrading the civilian capacity of US foreign policy machinery.

The third foundation of Obama's foreign policy is a relatively more peaceful approach to the Middle East. During the first year of his presidency, Obama tried to refurbish the United States' image abroad, especially in the Muslim world (Indyk et al., 2012). Therefore, he eased military operations in Iraq and Afghanistan in the following years while he maintained a focus on Al-Qaeda operatives in the region (Indyk et al., 2012, p. 108).

\section{Syria Policy}

Obama's Syria policy can be roughly categorized into two areas: before and after the Syrian civil war. In general, the Obama administration tried to restore its relations with Syria. However, after the Arab Spring and the uprising of the Syrian civil war, the responses of Obama's administration were mixed.

Before the uprising of the Syrian Civil War, Syria gave the Obama administration a cautious welcome, and Obama moved quickly to explore the possibility of improving relations (Hinnebusch et al., 2010, p. 24). Not only in Syria but also in the Middle East countries, Obama's image, which was different than his predecessor Bush, played a role in improving the US and regional states' relations. Also, recognizing the importance of improving relations with Syria, the Obama administration announced in June 2009 the return of the US ambassador to Damascus, which was left vacant in 2005 (Hinnebusch et al., 2010, p. 50; Kanat, 2016, p. 10). However, as Kanat (2016, p. 11) asserts, the restoration process of US-Syrian relations was disrupted by the Arab Spring and its impact on Syria. In other words, the Obama administration changed its course of action concerning Syria and realized that diplomatic efforts do not have any significant impact on the Assad regime (Zisser, 2013).

The first turning point of Obama's Syrian policy took place in 2011. Following the Assad regime's forceful action against the peaceful demonstrations and after much deliberation, President Obama took a major step forward in the US's policy towards Syria and stated that "for the sake of the Syrian people, the time has come for President Assad to step aside." (Kanat, 2016, p. 11). In other words, "only in May 2011 did US spokespersons, joined in the end by President Obama himself, begin to declare that the most appropriate solution to the crisis was for Assad to step down" (Zisser, 2013). The Obama administration also called for the United Nations to condemn the Syrian government (Greenberg, 2016, p. 2). Then, it closed its embassy in Damascus, and US officials started to participate in efforts of Syrian opposition such as the Friends of Syria forum that met in Tunisia and Istanbul (Sharp \& Blanchard, 2012). However, even 
though publicly stating the need for the removal of Assad, the US' efforts during this era were limited to statements and did not signal any concrete military action toward Syria (Sharp and Blanchard, 2012, p.2; Zisser, 2013).

The second turning point of Obama's Syria policy took place in 2012. In a statement in August 2012, President Obama declared that US policy toward Syria would change if the Assad administration uses or attempts to use chemical weapons (Ball, 2012). In other words, Obama issued a red line in Syria. Nonetheless, US actions following the statement were not sufficient to deter the Assad regime from using chemical weapons (Kanat, 2016, p. 11-12).

The third point of Obama's Syria policy took place in 2013. Obama reiterated the red line in Syria in his speech after the chemical attack on Ghouta in 2013. However, Obama was reluctant to intervene in Syria and emphasized the aim should not be overthrowing the Assad regime but to limited intervention in terms of reducing the chemical weapons capacity of the regime. Then, Obama canceled the military retribution for the regime's chemical attacks (Weiss, 2014).

The Syrian crisis became more complicated after 2013 with the involvement of regional and local actors in the conflict. In 2015, Russia launched a military intervention in Syria to help the Assad regime. Likewise, Iran, Hezbollah, more specifically, involved in the Syrian civil war to support the Assad regime. On the contrary, other regional actors such as Turkey and Qatar supported the Syrian opposition not only in diplomatic terms but also in military terms. Last but not least, several radical Islamic organizations, including ISIS, started to take part in the Syrian conflict. In other words, after 2013, the situation became much worse and complex.

Most articles and policy papers focus on the current situation in Syria blame the inefficiency of Obama's Syrian policy, particularly the decision not to intervene in Syria. It is important to note that most of the analyses depend heavily on realpolitik explanations. I argue that Obama's Syria policy, the decision not to intervene in Syria in particular, can be better explained by the other two approaches. These approaches are mass politics and psychological and cognitive explanations.

\section{Mass Politics and Obama's Syrian Policy}

Mass politics refers to public opinion and interest groups in the US political system. The first part of the mass politics approach is public opinion. In order to understand the role of public opinion in Obama's Syrian policy, it is vital to know how public opinion impacts US foreign policy. The importance of the role of public opinion in determining foreign policy has been proved by several scholars in the last forty years. Berinsky (2001, p. 12-13), for instance, shows that public opinion constrained US foreign policy towards Vietnam during the Johnson administration. It is important to stress that public opinion becomes much more critical in formulating US foreign policy when it comes to the use of force. In other words, US public opinion's willingness to use force, which varies in parallel to the reasons for using force, can be an important asset or constraint for US policymakers in the decision-making process of military intervention.

The second part of the mass politics approach is interest groups. There are several interest groups operate in the United States' political system with different motivations and features such as ethnic interest groups or business interest groups, and they all aim to influence US foreign policy in some manner. The influence of interest groups, particularly ethnic interest groups, on US foreign policy is undeniable (RisseKappen, 1991). The literature on interest groups' impact on US foreign policy focuses mostly on exploring specific ways or features of interest groups to affect US foreign policy significantly. There are several examples that can be given to show how interest groups are effective in determining US foreign policy. The American Israel Public Affairs Committee (AIPAC) is one of the most powerful interest groups in the United States that has a significant influence in shaping US foreign policy. It is successful in conveying its message that Israel is the only democracy within the region, and as a fellow democracy, it should receive unqualified support (Mearsheimer \& Walt, 2006, p. 35). It is widely known that it influences US foreign policy towards not only Israel but also towards the Middle East. The financial and military aid that Israel received from the US is mostly a result of the AIPAC's influence on US foreign policy and policymakers. The Cuban American National Foundation (CANF) can be given as another example to show interest groups' influence on determining US foreign policy. As an interest group, the CANF played a huge role in determining US foreign policy of Latin America in the Reagan era (Haney \& Vanderbush, 1999, p. 348). Likewise, it is fair to argue that financial interest groups also play a crucial role in the 
economic side of US foreign policy. In a nutshell, it is proven that both public opinion and interest groups are important factors that may play a role in shaping US foreign policy. Even though they alone cannot determine US foreign policy in general, they have the potential to affect specific decisions of US foreign policy towards a region or an issue.

\section{Understanding Obama's Syrian Policy through Mass Politics}

I argue that Obama's Syrian policy, the decision not to intervene specifically, was significantly affected by mass politics in two manners. These are a lack of US public support for military intervention and ineffective interest groups. In other words, since US public opinion is reluctant to send troops overseas after Iraq and Afghanistan experiences, and since there was not an efficient interest group to promote US intervention to Syria, Obama hesitated to intervene in Syria because of political costs.

Polls in 2013 that took place after the Assad's regime chemical attack shed light on Obama's reluctance to choosing military action against Syria. Even though Obama started to consider military action and called for a Congressional vote after the attacks, US public opinion was overwhelmingly opposed to military intervention. As Clement (2017) shows;

"In the month after the United States concluded that Syria had used chemical weapons in August 2013, three separate Washington Post-ABC News polls found clear majorities of the public opposed launching missile strikes in Syria. In the last of those surveys, 61 percent opposed strikes in response to Syria's use of chemical weapons, with opposition outpacing support by about a 2-to-1 margin. The margin of intense opinion was even starker: 45 percent said they "strongly opposed" military strikes."

"The Post-ABC poll also found overwhelming support for a diplomatic solution, with nearly 8 in 10 supporting a Russia-proposed plan to have Syria place its chemical weapons under control of the United Nations for eventual destruction."

Considering the public support for the military action after $9 / 11$ was eighty-six percent, it is fair to argue that Obama lacked public support for military action in Syria. Besides the realpolitik explanations, polls show us how public opinion may have affected Obama's Syria policy and military intervention specifically. It can also be seen in Obama's closing statement at the end of the G20 summit in 2013. President Obama stated that he could not persuade most of the American people that military action is the right thing to do (Hardman, 2013).

These poll results and their impact on Obama's Syrian policy is also compatible with the literature. Jentleson and Britton (1998, p. 415) examine US public opinion on the use of military force and assert that "if given a choice, the US public almost always prefers the less costly option- nonmilitary options." They also assert that US public opinion does not support the use of force to regime change in another country. Compatible with the literature, US public opinion overwhelmingly preferred the diplomatic solutions rather than a military action against Syria that had an impact on Obama's Syria policy.

Related to public opinion literature, there is another perspective that can be utilized to understand Obama's Syria policy: the role of elites in shaping Syria policy. According to Berinsky (2008, p. 975), elite conflict shapes public opinion concerning military action since the public use elite cues to decide. When political elites are united in their support for an intervention, the public is willing to support them. However, when prominent political actors take divergent stands on the wisdom of intervention, the public divides. The process of the authorization for military action to Syria, namely The Authorization for the Use of Military Force Against the Government of Syria to Respond to Use of Chemical, shows how elites took divergent positions in US military intervention to Syria and therefore affected US public opinion. The bill never received a floor vote in either the House or Senate (US Congress, 2013-2014). Put simply, public opinion, both its reluctance and elites' divergent positions, affected Obama's decision not to intervene in Syria.

In addition to US public opinion, the ineffectiveness of interest groups also played a role in Obama's Syria policy, particularly not intervening in Syria. Unlike other prominent examples such as the AIPAC or the CANF, there were not efficient and powerful interest groups that push military intervention in Syria. It is also compatible with literature. Haney and Vanderbush (1999) provide criteria for ethnic interest groups to be effective in US foreign policy decisions. According to them, 1) organizational strength, 2) membership unity, placement, and voter participation, 3) salience and the resonance of the message, 4) an open door, 5) permeability of and access to the government, and 6) mutually supportive relationships are vital for an ethnic interest group to influence US foreign policy. However, Syrian ethnic interest groups 
did not have organizational strength and membership unity. Likewise, there was not an open door for them to affect Obama's Syria policy. In that manner, it is fair to argue that since related interest groups were ineffective and did not have a chance to impact the White House, they could not pursue their own agenda regarding Syria and could not impact Obama's Syria policy and decisions.

In a nutshell, the mass politics approach is useful to understand Obama's Syria policy, particularly regarding military intervention. Since public opinion was extremely reluctant to send US troops to Syria and there was not an influential interest group that could impact the public opinion and the administration policies, it would have been hard for Obama to favor military options because of political costs. Therefore, he may have chosen civilian option instead of military intervention because of political costs.

\section{Psychological and Cognitive Explanations and Obama's Syria Policy}

Psychological and cognitive explanations refer to self-perception theory, schema theory, cognitive dissonance theory, and attribution theory. Self-perception theory is about how people know their own attitudes and beliefs. According to Daryl Bern's self-perception theory, 'individuals come to 'know' their attitudes, emotions, and other internal states, in part by observing their own behavior and the context in which they are acting" (Larson, 1989, p. 42). The theory argues that behavior leads to the development of attitudes by providing evidence of what we really believe (Larson, 1989, p. 43). Last but not least, as Larson (1989, p. 48) points it, self-perception theory is most likely to apply when a person's attitude is not yet fully crystallized or formed (Larson, 1989, p. 48).

Schema theory, on the other hand, presents "an image of the person as 'categorized' and 'labeler,' overwhelmed by sensations and information, trying to sort out what is important by developing a set of categories into which experiences can be conveniently classified." (Larson, 1989, p. 50) Larson (1989, p. 54) argues that three types of schemas are relevant for explaining foreign policymaker's perceptions of the world and their interpretation of ongoing events: scripts, metaphors, and personae. Per Larson (1989, p. 54-55);

"A cognitive script is a stereotyped sequence of events characterizing a well-known situation while personae are cognitive structures representing the personality characteristics and typical behaviors of certain "stock characters." Metaphors, on the other hand, is applied when to understand the social environment by matching what an individual is experiencing to a preconceived schema describing analogous situations in the past."

On the other hand, cognitive dissonance theory provides one possible explanation of the imperviousness of preconceived opinions to rational disconfirmation (Larson, 1989, p. 29). As Larson (1989, p. 29) puts it:

\section{"The underlying assumption of the theory is that people's beliefs are bighly interconnected and mutually coherent. When this harmony is disrupted by development of incompatible cognitions, a wave of cognitive or behavioral activity is stirred up until internal consistency is restored."}

Last but not least, attribution theory assumes that many attitudes or beliefs have their origins in people's efforts to understand the behavior of others (Larson, 1989, p. 37). As Larson (1989, p. 40) states:

"From the perspective of attribution theory, people actively seek out information and formulate causal explanations, and do not passively adopt the arguments of a persuasive communication. New attitudes are formed based on the person's own diagnosis of die causes of an event, not internalization of somebody else's conclusions."

\section{Understanding Obama's Syria Policy through Psychological and Cognitive Theories}

I argue that Obama's Syrian policy, the decision not to intervene specifically, was significantly affected by Obama's attitudes and can be explained by psychological theories. Before exploring psychological explanations of Obama's Syrian policy, I argue that three specific beliefs of Obama shaped his policymaking regarding Syria. The first belief is avoiding another Libya or Iraq. In April 2017, Obama stated that his biggest mistake was failing to plan for the day after intervening in Libya (Wyne, 2017). Likewise, Obama repeatedly stressed that he would not end up like the second President Bush (Goldberg, 2016, p. 52). The second belief that affected his decisions in Syria is choosing the civilian apparatus of the US government instead of military options. Among others, he stressed his commitment to a greater emphasis on civilian and diplomatic solutions rather than military options in his Nobel Prize speech by saying not talking does not work (Aaronson, 2003, p.145). Last but not least, the third belief that affected 
Obama's Syrian policy is his worldview. In an interview, Obama explicitly stated that he is an internationalist and idealist that supports promoting liberal democratic values, but he does not support promoting these values through military interventions (Goldberg, 2016, p. 60).

Provided specific beliefs of Obama that affected his Syria policy, I argue that Obama's Syria policy can be explained through these four psychological theories above. To reinforce my argument, I provide Obama's speeches and interviews during his service as the President of the United States for each theory.

The first psychological explanation is self-perception theory. This theory is about how people know their own attitudes and beliefs. When Obama was sworn into office in January 2009, he had already developed an activist vision of his foreign policy destiny: refurbishing the United States' image abroad, especially in the Muslim world; end the wars in Iraq and Afghanistan (Indyk et al., 2012). In other words, at the beginning of his term, he had his own beliefs about how to conduct US foreign policy. In addition to his beliefs on foreign policy, he also had a specific belief in combating terrorism: instead of embracing global war on terror, combatting terrorism in a relatively limited way be attacking al Qaeda operatives in Afghanistan (Indyk et al., 2012). However, after the Libya intervention, it is fair to argue that his attitudes changed. According to Goldberg (2016, p. 64):

"What sealed Obama's fatalistic view was the failure of his administration's intervention in Libya, in 2011.
That intervention was meant to prevent the country's then-dictator, Muammar Qaddafi, from slaughtering the
people of Benghari, as he was threatening to do. Obama did not want to join the fight; he was counseled by Joe
Biden and his first-term secretary of defense Robert Gates, among others, to steer clear. But a strong faction
within the national-security team — Secretary of State Hillary Clinton and Susan Rice, who was then the
ambassador to the United Nations, along with Samantha Power, Ben Rhodes, and Antony Blinken, who was
then Biden's national-security adviser- lobbied hard to protect Benghari, and prevailed. American bombs fell,
the people of Benghari were spared from what may or may not have been a massacre, and Qaddafi was captured
and executed. But Obama says today of the intervention, "It didn't work." The US, be believes, planned the
Libya operation carefully — and yet the country is still a disaster."

The failure of Libya intervention apparently changed Obama's attitudes not only in terms of military intervention but also regarding the Middle East and North Africa. In a couple of interviews, Obama stressed the change in his beliefs in two ways. The first one is related to cooperation regarding military intervention. As Goldberg (2016, p. 65) shows, he stated:

"When I go back and I ask myself what went wrong," Obama said, "there's room for criticism, because I had more faith in the Europeans, given Libya's proximity, being invested in the follow-up," he said. He noted that Nicolas Sarkosy, the French President, lost his job the following year. And he said that British Prime Minister David Cameron soon stopped paying attention, becoming "distracted by a range of other things."

The second change in Obama's beliefs is regarding the Middle East and North Africa. Even though he was committed to change US foreign policy towards the Middle East in the early years of his presidency, he later changed his attitudes towards these two regions. As can be seen in one of the interviews, Obama told a former colleague from the Senate:

"There is no way we should commit to governing the Middle East and North Africa; that would be a basic, fundamental mistake." (Goldberg, 2016, p. 65).

Given Obama's responses in the interviews, his core beliefs, and his decisions regarding Syria, it is possible to argue that self-perception theory can explain Obama's Syria policy, particularly not to intervene in Syria. At the beginning of his presidency, Obama had his own beliefs and attitudes: more prone to a peaceful solution in the Middle East. He had his arguments compatible with his beliefs concerning US foreign policy, particularly towards the Middle East. However, Libyan intervention affected his attitudes. He developed new beliefs and attitudes toward the Middle East. It is possible to say that his decision not to intervene in Syria is a result of a change in his attitudes and beliefs after the failed Libyan intervention. In other words, it is fair to argue that he did not prefer a military intervention in Syria because he had no faith in other countries that they would follow up the US, and he thought the Middle East was best avoided. In some manner, he learned from his behavior in Libya and did not implement the same option to the Syrian case.

The second psychological explanation is schema theory. This theory is mostly about categorizing and labeling in sorting out what is important. After a thorough examination of Obama's speeches and interviews, I argue that schema theory can also explain Obama's Syria policy since he repeatedly used 
categorization of information he received. Among others, he explicitly categorized and labeled four different phenomena. These are the categorization of the Middle East leaders, categorization of threats from the Middle East, categorization of Syrian civil war, and categorizing of the Syrian opposition.

During the beginning of the uprising in Syria, as a President of the United States, Obama received a significant amount of information from the US intelligence community about the situation in Syria. However, his speeches and interviews with the officials from the Obama administration show that Obama considered Bashar Assad as a classic example of a Middle East leader. He basically applied a cognitive script in the Syrian situation. A former Middle East adviser to Obama, Dennis Ross, then explained Obama's thoughts as follows:

\title{
"He [Obama] thought Assad would go the way Mubarak went, referring to the quick departure of Egyptian President Hosni Mubarak in early 2011, a moment that represented the acme of the Arab Spring." (Goldberg, 2016, p. 52).
}

Not only Obama's thoughts on the Middle East leaders but also his thoughts on the threats from the Middle East affected his Syria policy as well. In one of the interviews, Obama said that he believes that only a handful of threats in the Middle East conceivably warranted direct US military intervention (Goldberg, 2016, p.53). Obama expressed that these threats are:

\begin{abstract}
"The threat posed by al-Qaeda; threats to the continued existence of Israel ("It would be a moral failing for me as president of the United States" not to defend Israel, he [Obama] once told me); and, not unrelated to Israel's security, the threat posed by a nuclear-armed Iran. The danger to the United States posed by the Assad regime did not rise to the level of these challenges." (Goldberg, 2016, p. 53).
\end{abstract}

In other words, Obama categorized the threats from the Middle East and believed that the Assad regime was not a solid threat that requires US military intervention comparing the other threats from the region. In that manner, since Syria was not a solid threat, it did not require a military solution per Obama.

Likewise, it is fair to argue that Obama considers Syria as a different example than previous US military intervention or humanitarian crises. For Obama, the Syrian civil war belongs to a different category than Rwanda. Syria is much more complex than Rwanda, and it requires much more commitment. In an interview, Obama stated the differences as follows.

"I asked Obama whether he would have sent the Marines to Rwanda in 1994 to stop the genocide as it was happening, had he been President at the time. "Given the speed with which the killing took place, and how long it takes to crank up the machinery of the US government, I understand why we did not act fast enough," he said. "Now, we should learn from that. I actually think that Rwanda is an interesting test case because it's possiblenot guaranteed, but it's possible — that this was a situation where the quick. application of force might have been enough." He related this to Syria: "Ironically, it's probably easier to make an argument that a relatively small force inserted quickly with international support would have resulted in averting genocide [more successfully in Rwanda] than in Syria right now, where the degree to which the various groups are armed and hardened fighters and are supported by a whole host of external actors with a lot of resources requires a much larger commitment of forces." (Goldberg, 2016, p. 72).

It is also important to note that Obama categorized Syrian opposition groups. Even though at the end of his presidency, the Obama administration started to support Kurdish militia groups such as YPG People's Protection Units in Kurdish- in the Syrian civil war, between 2011 and 2013, he considered the Free Syrian Army (FSA) as a legitimate local partner. In other words, while other rebel groups were not categorized as somehow legitimate, the FSA was considered as a relatively legitimate actor in the Syrian civil war. Hence, it became the major local partner of the United States regarding the Syrian civil war (Weiss, 2014).

The third psychological explanation is cognitive dissonance theory. This theory is mostly about restoring the internal consistency of a person when his coherent beliefs are distupted. After a thorough examination of Obama's speeches and interviews, I argue that cognitive dissonance theory can also explain Obama's Syria policy since he repeatedly refused to change his beliefs even though there were contradictory intelligence or arguments to his beliefs on the Syrian civil war. At the beginning of his first term and before the Syrian uprising, he strictly refused the necessity of any military intervention in a foreign country by arguing that complex problems need more than a military response (Aaronson, 2003, p. 138-139). 
Obama strictly refused military intervention in Syria, which contradicted his beliefs and argued that the Syrian civil war is not a direct national security threat even though some White House and US government officials repeatedly told him the otherwise. Particularly, when the criticism of his Syrian policy boosted after the Assad regime used chemical weapons against the Syrian people in 2013, he did not step back from his previous position and did not consider military intervention seriously even though most US political elite called him to do so. He stated in an interview after he was asked about his Syria policy:

Interviewer: "Oftentimes when you get critics of our Syria policy, one of the things that they'll point out is 'You called for Assad to go, but you didn't force bim to go. You did not invade.' and the notion is that if you weren't going to overthrow the regime, you shouldn't have said anything.

Obama: That's a weird argument to me, the notion that if we use our moral authority to say, 'This is a brutal regime, and this is not how a leader should treat his people,' once you do that, you are obliged to invade the country and install a government you prefer." (Goldberg, 2016, p. 60).

Another example of examining Obama's Syria policy through cognitive dissonance theory is his interaction with State Secretary John Kerry. In 2015, Kerry repeatedly asked Obama to launch missiles at specific regime targets in Syria, under cover of night, to "send a message" to the regime (Goldberg, 2016, p. 77). According to Goldberg (2016), Obama resisted Kerry's requests and seemed to have grown impatient with his lobbying. Once when Kerry handed Obama a written outline of new steps to bring more pressure to bear on Assad, Obama said, “Oh, another proposal?” (Goldberg, 2016, p. 77-78).

As can be seen in the examples, Obama repeatedly and strictly refused any other option, including military intervention, in Syria that contradicts his beliefs on Syria that requires more diplomacy rather than military intervention.

The last psychological explanation is attribution theory. This theory is mostly about the role of personal interpretations and experiences in shaping attitudes. Regarding Obama's Syria policy, there are at least two points that can be explained by attribution theory. These are Obama's personal experience with Russian president Vladimir Putin and his relationship with his advisors. Related to the Syrian crisis, Obama had been severely criticized by prominent political figures and pundits. Criticism mostly focused on Obama's reluctance to choose military options. Some pundits argued that Obama's reluctance was an opening for Russian's involvement in Syria and led to Putin's more aggressive policies. However, Obama disagreed based on his personal experiences with Putin. In an interview, Obama said that his relationship with Putin does not comfort common perceptions. He expressed his thought as follows:

"Obama told me, Putin is not particularly nasty. "The truth is, actually, Putin, in all of our meetings, is scrupulously polite, very frank. Our meetings are very businesslike. He never keeps me waiting two bours like be does a bunch of these other folks." Obama said that Putin believes his relationship with the US is more important than Americans tend to think. "He's constantly interested in being seen as our peer and as working with us, because he's not completely stupid. He understands that Russia's overall position in the world is significantly diminished. And the fact that he invades Crimea or is trying to prop up Assad doesn't suddenly make him a player. You don't see him in any of these meetings out here helping to shape the agenda. For that matter, there's not a G20 meeting where the Russians set the agenda around any of the issues that are important." (Goldberg, 2016, p. 75).

Based on his personal experiences, Obama built his Syria policy contrary to common perceptions. Even though Russia expanded its role in the Middle East, particularly in Syria, his attitude did not change significantly. Not only Obama himself but also his advisors were important actors in determining Obama's Syria policy. Like Obama, his advisors also participated in bilateral meetings with Russian Federation. Kanat (2016, p.10) argues that the position of these individuals closely matches the worldview and foreign policy vision of President Obama. Considering they had similar worldviews and similar experience with Russian and Syrian officials, they may have had similar conclusions regarding Syria that Obama had.

\section{Conclusion}

Foreign policy is an essential part of international relations. States implement their foreign policies with several aims, such as enhancing their interests or cultivating their relations with other states. Even though foreign policy analysis is not as old as the practice itself, it has been studied by researchers for more than fifty years. Relevant literature and current analyses on foreign policy decision making tend to 
put a greater emphasis on realpolitik assumptions. However, these analyses overlook the factors that shape foreign policy and cannot explain the decision-making processes adequately.

Obama's Syria policy is a perfect example that shows the failure of realpolitik arguments in explaining foreign policy decisions. Theoretically, President Obama should have intervened in the Syrian conflict around 2012 to prevent the increase of Russian and Iranian influence in Syria and to ensure stabilization of the region. However, on the contrary to realpolitik expectations, he did not implement such strategy. Instead, he particularly refrained from intervening in Syria in military terms. As a result, his Syria policy had long been criticized by the US political elites, scholars, and pundits.

This paper shows that Obama's Syria policy can be better explained by two other approaches: mass politics and psychological and cognitive approaches. The mass politics approach is useful to explore the role of public opinion and interest groups in foreign policy decision making processes. Research conducted shows that Obama's decision not to intervene in Syria is a result of two elements: a lack of US public support for military intervention and ineffective interest groups.

Obama's statements between 2011 and 2013 imply that he was not in favor of military options in the Syrian conflict. He repeatedly stated Syrian conflict should be resolved through diplomatic channels and methods in this era. However, Assad's regime chemical attack on Ghouta in 2013 was a game-changer. After the attack, President Obama specifically stated that the Assad regime crossed his administration's red line. Authorization of military intervention into Syria was expected after this speech. However, he did not implement a military solution because there was a lack of US public support for military intervention. As the polls in the US after the attack in Ghouta present, the majority of US citizens were reluctant to send US military to Syria, particularly as a result of relatively failed military operations in Afghanistan and Iraq. Therefore, Obama could not implement military intervention into Syria even though he might prefer it.

In addition to the lack of public support, there was not an efficient interest group to promote US intervention in Syria as well. As can be seen in the impact of AIPAC on US-Israeli relations, interest groups are important actors in influencing US foreign policy decisions. In order to build a comprehensive foreign policy strategy, presidents should receive support from the US legislative actors as well. This support of legislative actors to the President in a foreign policy issue is mostly a result of interest groups' efforts. Therefore, a lack of interest groups to promote military intervention into Syria also affected Obama's decision-making processes regarding Syria. In a nutshell, contrary to realpolitik, Obama chose not to intervene in Syria because lack of public support and effective interest groups would have brought him political costs if he chose to do so.

Extensive research on Obama's statements and interviews show that Obama's psychological and cognitive features also played an essential role in his decision regarding Syria. First, there are three core beliefs of Obama, which shaped his policymaking not only regarding Syria but also in general. These are the need to avoid another Libya or Iraq, the need to prefer civilian solutions whenever possible, and the need to promote liberal democratic values. In a statement in 2017, Obama stressed that he prefers nonmilitary solutions regarding the Syrian conflict because he does not want another failed intervention of the US military as in Libya. Further, in the other statements, he specifically points out that he is an internationalist who believes in promoting liberal values, and he chooses civilian options rather than military ones whenever possible. However, if military action is a must, he prefers a limited one. In other words, on the contrary to realpolitik expectations, President Obama did not choose to authorize a military intervention into Syria because it would have been against his core beliefs regarding foreign policymaking.

In addition to his core beliefs, two factors also played a role in his decision regarding Syria. These are cognitive categorization and personal interactions. Obama's Syria policy was shaped by his cognitive categorization of regions, threats, and leaders. Statements and interviews between 2011 and 2017 show that Obama believes that North Africa and the Middle East are chronically destabilized regions, and US intervention there is mostly pointless. Therefore, it does not make sense to him to militarily intervene in Syria. Available data also shows that Obama considered Bashar Assad a typical example of a Middle Eastern leader and believed that the Syrian conflict did not pose a serious threat to US national security. Hence, military intervention into Syria was not compulsory, according to him. In addition, his personal diplomatic encounters with the leaders of the region and Russian President Vladimir Putin shaped his 
policy of Syria. Based on his interactions with Putin, it can be argued that he did not perceive Russian involvement in Syria as a major threat.

In a nutshell, this article proves that mass politics and cognitive and psychological approaches are better in explaining Obama's Syria policy. On the contrary to realpolitik explanations, these approaches do not overlook factors that shaped Obama's foreign policy decisions. Further studies in foreign policy analysis should utilize these approaches to provide more comprehensive explanations.

\section{Ethical Declaration}

In the writing process of the study titled 'Understanding the Obama Administration's Syria Policy", there were followed the scientific, ethical and the citation rules; was not made any falsification on the collected data and this study was not sent to any other academic media for evaluation. Since the data set is used in this article, ethics committee approval is not required.

\section{References}

Aaronson, M. (2013). Interventionism in US foreign policy from Bush to Obama. In Obama's Foreign Policy (pp. 134148). Routledge.

Bajevich, A. J. (7th December, 2016). Barack Obama's Crash Course in Foreign Policy. The Nation. Retrieved from. https://www.thenation.com/article/archive/barack-obamas-crash-course-in-foreign-policy/ Access: $06 / 01 / 2021$

Ball, J. (21st August, 2012). Obama issues Syria a 'red line' warning on chemical weapons. The Washington Post. Retrieved from. https:// www.washingtonpost.com/world/ national-security/ obama-issues-syria-red-line-warning-on-chemicalweapons/2012/08/20/ba5d26ec-eaf7-11e1-b811-09036bcb182b story.btml Access: 06/01/2021

Berinsky, A. J. (2001, April). Public Opinion During the Vietnam War: A Revised Measure of the Public Will. In Annual Meeting of the Midwest Political Science Association.

Berinsky, A. J. (2008). Assuming the costs of war: Events, elites, and American public support for military conflict. The Journal of Politics, 69(4), 975-997.

Clement, S. (7th April, 2017). Americans hated the idea of strikes against Syria in 2013. But Trump's could be different. The Washington Post. Retrieved from. https://www.washingtonpost.com/news/thefix/wp/2017/04/07/military-strikes-in-syria-were-very-unpopular-four-years-ago-but-trumps-could-bedifferent/ Access: 06/01/2021

Greenberg, D. (29th December, 2016). Syria will stain Obama's legacy forever. Foreign Policy. Retrieved from. https://foreignpolicy.com/2016/12/29/obama-never-understood-how-history-works/ Access: 06/01/2021

Guiora, A. N. (2011). Intervention in libya, yes; intervention in syria, no: Deciphering the obama administration. Case W. Res. J. Int'l L., 44, 251.

Haney, P. J., \& Vanderbush, W. (1999). The role of ethnic interest groups in US foreign policy: the case of the Cuban American National Foundation. International Studies Quarterly, 43(2), 341-361.

Hardman, I. (6th September, 2013). Barack Obama and public opinion on Syria. The Spectator.

Hinnebusch, R., Kabalan, M. J., Kodmani, B., \& Lesch, D. (2010). Syrian Foreign Policy and the United States: From Bush to Obama. Syria Studies, 2(1), 1-58.

Holland, E. C. (2011). Barack Obama's foreign policy, just war, and the irony of political geography. Political Geography, 2(30), 59-60.

Indyk, M. S., Lieberthal, K. G., \& O'Hanlon, M. E. (2012). Scoring Obama's foreign policy: A progressive pragmatist tries to bend history. Foreign Affairs, 29-43.

Jentleson, B. W., \& Britton, R. L. (1998). Still pretty prudent: Post-cold war American public opinion on the use of military force. Journal of Conflict Resolution, 42(4), 395-417.

Kanat, K. B. (2016). A Tale of Four Augusts: Obama's Syria Policy (Vol. 7). The SETA Foundation at Washington, DC.

Krieg, A. (2016). Externalizing the burden of war: the Obama Doctrine and US foreign policy in the Middle East. International Affairs, 92(1), 97-113.

Larson, D. W. (1989). Origins of containment: A psychological explanation. Princeton University Press.

Mearsheimer, J. J., \& Walt, S. M. (2006). The Israel lobby and US foreign policy. Middle East Policy, 13(3), 29-87.

Pavgi, K. (17th November, 2011). Barack Obama's Foreign Policy. Foreign Policy. Retrieved from. https://foreignpolicy.com/2011/11/17/barack-obamas-foreign-policy/ Access: 06/01/2021

Risse-Kappen, T. (1991). Public opinion, domestic structure, and foreign policy in liberal democracies. World Politics, 43(4), 479-512.

Sharp, J. M., \& Blanchard, C. M. (2012, May). Syria: unrest and US Policy. In Congressional Research Service (CRS) Report for the Congress.

The US Congress. (2013-2014). S.J.Res.21 - Authorization for the Use of Military Force Against the Government of Syria to Respond to Use of Chemical Weapons

Titus, A. (14th March, 2018). Obama Owns the Syria Crisis. National Review. Retrieved from. https://www.nationalreview.com/2018/03/syria-crisis-obama-foreign-policy-disaster/ Access: 06/01/2021 
Weiss, M. (2nd January, 2014). The Unraveling: How Obama's Syria Policy Fell Apart. Politico. Retrieved from. https://www.politico.com/magazine/story/2014/01/how-obamas-syria-policy-fell-apart-101704 Access: 06/01/2021

Wyne, A. (6th February, 2017). President Obama's Foreign Policy Legacy. Kennedy School Review. Retrieved from. https://ksr.hkspublications.org/tag/president-obama/ Access: 06/01/2021

Zisser, E. (2013). The Failure of US Policy toward Damascus. Middle East Quarterly, 59-65.

\section{TÜRKÇE GENIŞ ÖZET}

Başkan Obama'nın Suriye politikası, akademisyenler ve politika analistleri tarafından uzun süredir sorgulanmakta ve eleştirilmektedir. Bugüne kadar Başkan Obama Suriye İç Savaşı'nı daha da kötüleştirmekle, liderlik yapamamakla ve etkisiz kalmakla suçlanmıştır. Ancak getirilen eleştirilerin büyük bir kısmı reel politik unsurlar göz önünde bulundurularak yapılmıştır. Reel politik unsurların temel olarak alındığı dış politika analizlerinde karar alma sürecini etkileyen diğer unsurlar göz ardı edilmektedir. Bu sebeple, bu tarz çalışmalar Obama'nın Suriye politikasını yeterli olarak açıklayamamaktadır. Bu makale, Obama'nın Suriye politikasının daha kapsamlı bir açıklamasını sağlamayı amaçlamaktadır. Bu makalede, Obama’nın Suriye politikasının başka iki yaklaşımla daha iyi açılanabileceğini savunulmaktadır. Bu yaklaşımlar, kitle siyaseti ve psikolojik ve bilişsel açıklamalardır.

Kitle siyaseti yaklaşımı, dış politika karar alma süreçlerinde kamuoyu ve çıkar gruplarının rolünü ele almaktadır. Yapılan araştırma sonucu Obama'nın Suriye'ye müdahale etmeme kararının iki unsurdan kaynaklandığı bulunmuştur. Bu unsurlar; ABD'nin Suriye'ye yönelik askeri müdahalesine yönelik kamuoyu desteğinin olmaması ve bu yönde çalışan etkili bir çıkar grubunun bulunmamasıdır.

2011 ve 2013 yılları arası Obama'nın açıklamaları incelediğinde Obama'nın Suriye'deki karışıklı̆̆ın çözümüne yönelik askeri seçeneklerden yana olmadığı görülmüştür. Bu dönemde, Başkan Obama sorununun diplomatik kanallar ve yöntemlerle çözülmesi gerektiğini defalarca ifade etmiştir. Ancak, Esad rejiminin 2013 ylında Ghouta'ya kimyasal saldırı düzenlemesi bir dönüm noktası olmuştur. Saldırının ardından Başkan Obama, Esad rejiminin Obama yönetiminin bu konudaki kırmızı çizgisini aştığını özellikle belirtmiştir. Bu konuşmanın ardından Obama’nın Suriye'ye yönelik askeri müdahale izni vermesi beklenmiştir. Ancak, Suriye'ye askeri müdahale için ABD kamuoyu desteği sağlanamamı̧tır. Afganistan ve Irak'taki nispeten başarısız askeri operasyonların bir sonucu olarak ABD kamuoyu, ordusunun Suriye'ye gönderilmesi konusunda isteksiz olmuştur. Bu nedenle Obama, Suriye'ye askeri müdahaleyi tercih etmiş olsa dahi uygulayamamıştır.

Kamuoyu desteğinin noksanlığına ilaveten ABD'nin Suriye'ye müdahalesini teşvik edecek yönde çalş̧malar gerçekleştiren etkin bir çıkar grubu da bulunmamaktadır. AIPAC'ın Amerikan-İsrail ilişkileri üzerindeki etkisinde görülebileceği üzere, çıkar grupları $\mathrm{ABD}$ dış politika kararlarının oluşturulmasında önemli aktörlerdir. ABD Başkanları kapsamlı ve başarılı bir dış politika stratejisi belirleyebilmek ve uygulamak için yasama organının desteğine muhtaçtır. Bu destek ise genellikle çıkar gruplarının çabalarının sonucu olarak oluşmaktadır. Bu nedenle, Suriye'ye askeri müdahaleyi teşvik edecek çıkar gruplarının eksikliği de Obama'nın Suriye politikasını belirleyen temel faktörlerden birisi olmuştur. Özetle, reel politik beklentilerin aksine, Başkan Obama Suriye'ye müdahale etmemeyi seçmiştir. Bu kararın en temel sebeplerinden birisi kamuoyu desteği ve etkin çıkar gruplarının olmaması sebebiyle böyle bir seçimin Obama'ya siyaseten maliyetli olacak olmasıdır.

Obama'nın açıklamaları ve röportajları üzerine yapılan kapsamlı araştırma, Obama'nın psikolojik ve bilişsel özelliklerinin de Suriye ile ilgili kararında önemli bir rol oynadığını göstermektedir. Obama'nın genel olarak dış politika yapımını şekillendiren üç temel inancı olduğu saptanmıştır. Bu inançlar; başka bir Libya ya da Irak'tan kaçınma gerekliliği, mümkün oldukça sivil çözümleri tercih etme gerekliliği ve liberal demokratik değerlerin teşvik edilmesinin gerekliliğidir. Obama, 2017'de yaptığı bir açıklamada ABD ordusunun Libya'da olduğu gibi göreceli olarak başarısız bir müdahalesini daha istemediği için Suriye'de askeri olmayan çözümleri tercih ettiğini vurgulamıştır. Dahası, diğer açıklamalarında, liberal değerleri desteklemeye inanan bir enternasyonalist olduğuna ve mümkün olduğunca askeri seçeneklerden ziyade sivil seçenekleri tercih ettiğine özellikle işaret etmiş̧ir. Buna rağmen, askerî harekât gerçekleştirmek zorunluluk haline geldiğinde ise sınırlı bir müdahaleyi tercih ettiğini belirtmiştir. Bu bağlamda, reel politik beklentilerin aksine, Başkan Obama'nın, dış politika konusundaki temel inançlarına aykırı olacağı için Suriye'ye askeri bir müdahale yetkisi vermediği tespit edilmiştir. 
Obama'nın dış politikasını şekillendiren temel inançlarına ilaveten, Suriye ile ilgili kararında iki faktör daha rol oynamıştır. Bunlar bilişsel sınıflandırma ve kişisel etkileşimlerdir. Diğer bir deyişle, Obama'nın Suriye politikası, bölgeleri, tehditleri ve liderleri bilişsel olarak sınıflandırmasıyla şekillenmiştir. 2011 ve 2017 yılları arasında yaptı̆̆ açıklamalar ve verdiği röportajlar, Obama'nın Kuzey Afrika ve Orta Doğu'nun kronik olarak istikrarsızlaştırılmış bölgeler olduğuna ve oraya gerçekleştirilecek $\mathrm{ABD}$ müdahalesinin çoğunlukla anlamsız olduğuna inandığını göstermektedir. Bu nedenle Suriye'ye askeri müdahalede bulunmanın mantıksız olduğuna inandığı saptanmıştır. Ayrıca, mevcut verilerin analizi sonucu, Obama'nın Beşar Esad'1 tipik bir Ortadoğu lideri olarak gördüğünü ve Suriye'deki karışıklığın ABD'nin ulusal güvenliği için ciddi bir tehdit oluşturmadığına inandığını göstermiştir. Dolayısıyla Obama’ya göre Suriye'ye askeri müdahale bir zorunluluk oluşturmamıştır. Son olarak, bölge liderleri ve Rusya Devlet Başkanı Vladimir Putin ile kişisel diplomatik görüşmelerinin de Obama'nın Suriye politikasını şekillendirdiği saptanmıştır. Obama'nın Rusya'nın Suriye'ye müdahalesini büyük bir tehdit olarak algilamadığı görülmüştür.

Özetle, bu makale, kitle siyasetinin ve bilişsel ve psikolojik yaklaşımların Obama'nın Suriye politikasını açıklamada daha iyi olduğunu kanıtlamıştır. Reel politik açıklamaların aksine, bu yaklaşımlar Obama'nın dış politika kararlarını şekillendiren faktörleri gözden kaçırmamışııı ve analize dahil etmiştir. Dış politika analizi konusunda gelecekte yapılacak çalışmalarda bu yaklaşımların kullanılmasını daha kapsamlı çalışmalara yol açacağı düşünülmektedir. 